\title{
Communication
}

\section{Winter Zooplankton in a Small Arctic Lake: Abundance and Vertical Distribution}

\author{
Vladimir G. Dvoretsky (D) and Alexander G. Dvoretsky *(D)
}

check for

updates

Citation: Dvoretsky, V.G.; Dvoretsky, A.G. Winter Zooplankton in a Small Arctic Lake: Abundance and Vertical Distribution. Water 2021, 13, 912. https://doi.org/10.3390/w13070912

Academic Editor: Artem Y. Sinev

Received: 24 February 2021

Accepted: 24 March 2021

Published: 26 March 2021

Publisher's Note: MDPI stays neutral with regard to jurisdictional claims in published maps and institutional affiliations.

Copyright: (c) 2021 by the authors. Licensee MDPI, Basel, Switzerland. This article is an open access article distributed under the terms and conditions of the Creative Commons Attribution (CC BY) license (https:/ / creativecommons.org/licenses/by/ $4.0 /)$.
Murmansk Marine Biological Institute (MMBI), 183010 Murmansk, Russia; v-dvoretsky@yandex.ru * Correspondence: ag-dvoretsky@yandex.ru

\begin{abstract}
Zooplankton assemblages are of great importance in aquatic food webs because they link lower (microplankton) and higher trophic levels (top predators). Small water bodies in the Arctic regions of Russia are less studied in winter because of severe ice conditions. For this reason, we analyzed the winter zooplankton community in Lake Kulonga (western coast of Kola Bay, Barents Sea). A total of 9 taxa were found in the samples. The total abundance varied from 200 to 1320 ind. $\mathrm{m}^{-3}$, averaging 705 ind. $\mathrm{m}^{-3}$. The total zooplankton biomass was $1.8-72.8 \mathrm{mg}$ of wet mass $\mathrm{m}^{-3}$ with an average of $30 \mathrm{mg} \mathrm{m}^{-3}$. These parameters were lower than in other Russian Arctic and subarctic lakes in summer. Old copepodites of Cyclops spp. dominated the zooplankton community at deep-water stations in terms of the total abundance consisting of 24-33\%. The copepod Macrocyclops albidus prevailed in terms of the total zooplankton biomass comprising 30-33\% at deep-water stations while Cyclops scutifer and copepodites Cyclops spp. had the highest biomass at shallow water stations. Vertical distribution demonstrated different patterns at neighboring stations, probably as a result of differences in the density of fish predators.
\end{abstract}

Keywords: freshwater zooplankton; copepods; vertical distribution; Lake Kulonga; Arctic

\section{Introduction}

The significance of plankton for freshwater, brackish, and marine ecological systems is unquestionable [1-4]. Zooplankton organisms present one of the main constituents in aquatic food webs, they link primary producers with the higher trophic levels both in freshwater and marine environments [5-8]. Planktonic animals serve as a major food source for various freshwater fish determining the total production in water bodies. Because many Copepoda, Cladocera, and Rotifera are filter-feeding organisms with relatively short lifespans and their taxonomical identification is easier than in the case of phytoplankton, zooplankton assemblages may be considered as good biological indicators of environmental conditions and shifts of hydrological regimes in freshwater ecosystems [9]. Their composition and abundance may reflect changes in aquatic environments under modern climatic fluctuations and anthropogenic impacts [10,11]. Zooplankton of the sub-Arctic and Arctic lakes are well studied, but the bulk of the data are obtained during summer seasons [12-16]. In general, the trophic structure of zooplankton in Arctic lakes is considered to be simple compared to boreal waters $[13,14]$.

Polar areas are characterized by significant seasonal changes in temperature, light regime, and aquatic production. Furthermore, the polar freshwater ecosystems are strongly affected by low temperatures and changing ice cover. The winter period in the Arctic is a less investigated season because the ice cover makes the lakes more difficult to study. A traditional opinion about Arctic freshwater and marine ecology is that most biological processes at high latitudes are reduced to a minimum during the polar night due to the reduction in light and low food availability. However, some previous investigations have shown that both freshwater and marine environments demonstrate life activity despite low productivity during winter conditions [17]. It has been found that the light penetrating into the water from the ice and snow may provide an energy input that is high enough for 
several planktonic animals to be active [7,17]. Recently, Norwegian authors have shown active vertical migrations of zooplankton [18] and bioluminescence levels indicative of functional activity in plankton biota [19]. Further findings have confirmed that Arctic organisms can respond to light levels undetectable by the human eye [20].

Small lakes are characterized by the short distance between the pelagic and the bottom habitat and the environmental factors weekly affecting the horizontal and vertical biotic gradients in these aquatic systems [5,21-23]. Lake Kulonga is situated on the western coast of Kola Bay (Murmansk oblast, Barents Sea region). Plankton fauna of the lake and adjacent small water bodies are less studied and, therefore, their investigations may be of interest for understanding plankton ecology in Arctic regions. Recent climatic changes in the Arctic, especially warming processes, lead to a reduction of Arctic sea ice cover and thickness as well as seasonal snow cover duration in lake systems [24]. These shifts can affect local aquatic organisms, their interactions, and more precisely ecosystem processes. Therefore, studying winter under-ice plankton may help in better understanding the ecosystem responses to these environmental fluctuations.

The western coast of Kola Bay near the village of Belokamenka $\left(69^{\circ} 4^{\prime} 51^{\prime \prime} \mathrm{N}, 33^{\circ} 10^{\prime} 9^{\prime \prime} \mathrm{E}\right)$ is an area selected to establish a complex for manufacturing large marine structures (CMLS) to supply Russian oil and gas industries in the Barents and Kara Seas. This complex now includes production and warehouse halls, docks, terminals, local infrastructure, and roads. Construction work began in 2018 and this process is still ongoing. Such a large-scale project and its further expansion would require substantial amounts of freshwater. Lake Kulonga is considered a potential source of water. Anthropogenic impacts on the local ecosystem can change the total productivity in the lake and affect the zooplankton community, which can be considered as a good indicator of potentially negative processes.

The aim of this paper is to report the species composition, abundance, biomass, and the vertical distribution of the zooplankton community in Lake Kulonga in winter as a basis for further water quality assessment of this lake under anthropogenic pressure.

\section{Materials and Methods}

Lake Kulonga is an oligotrophic lake and it has an ice-tectonic origin, as do many other lakes of the Murmansk region. The coast of the lake, in general, is low but there are some hills. An exception is the northwestern coast where shores are abrupt and composed of rocks or their products (stones and boulders). Due to such a complex origin, maximum depths in the lake are registered in the north-western part, the area of tectonic breaks. In the mid-part of the lake, depth does not exceed $15 \mathrm{~m}$ but in the south-eastern part, it is about $9 \mathrm{~m}$ [25].

The study site is a forest-tundra area with birch as a dominating flora. There are single pines, spruces, and willows. This lake is $2.61 \mathrm{~km}^{2}$ in area and $4.8 \mathrm{~km}$ long, averages $1.57 \mathrm{~km}$ in width, and has a maximum depth of $33 \mathrm{~m}$. The coastline is weakly indented, and its total length is about $14.8 \mathrm{~km}$ [25].

During the study period, the lake was covered with ice and snow and an ice auger was used to drill holes in the ice (Figure 1). Sampling was conducted on 3-4 March 2016 at four stations with three replicates at each station (Figure 2). In general, weather conditions (air temperature, wind speed, and humidity) were similar during the sampling events. Light intensity was similar at stations 1, 2, 4 (moderate cloudiness) while higher light intensity was recorded at station 3 due to low cloudiness.

Depth was measured with a marked rope attached to a sampling bottle. Temperatures at the surface and bottom were measured with a thermometer $\left( \pm 0.1^{\circ} \mathrm{C}\right)$. Depth at stations varied from 2 (St. 4) to $24 \mathrm{~m}$ (St. 2) (Table 1). Ice during the study period was covered with snow. Snow thickness was measured to be $15-40 \mathrm{~cm}$ in the open area and $50-55 \mathrm{~cm}$ near the coast. Ice thickness was $60-65 \mathrm{~cm}$. 

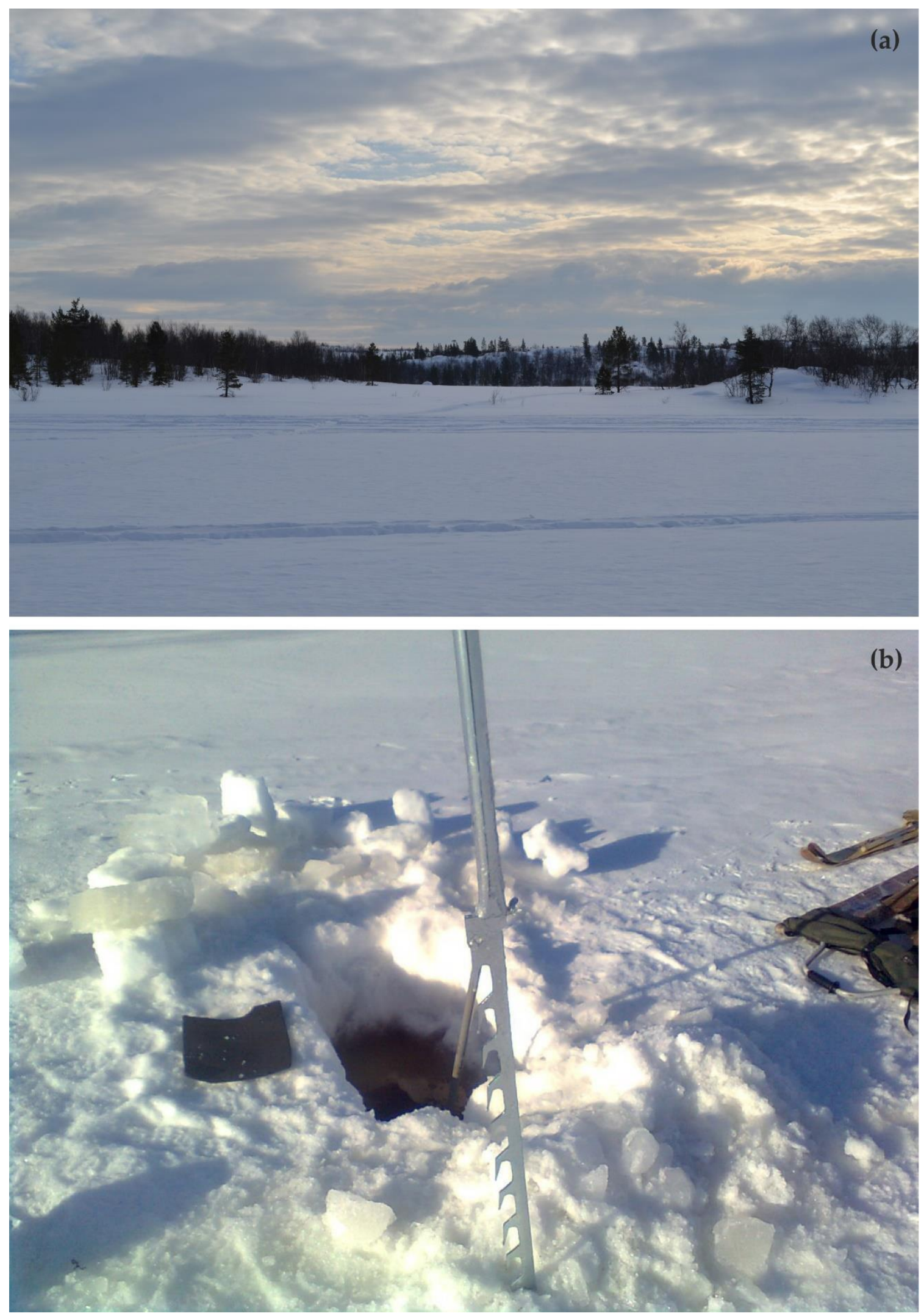

Figure 1. Lake Kulonga, March 2016. North-eastern coast, snow thickness $40 \mathrm{~cm}$ (a); a hole for zooplankton sampling, ice thickness $63 \mathrm{~cm} \mathrm{(b).}$ 


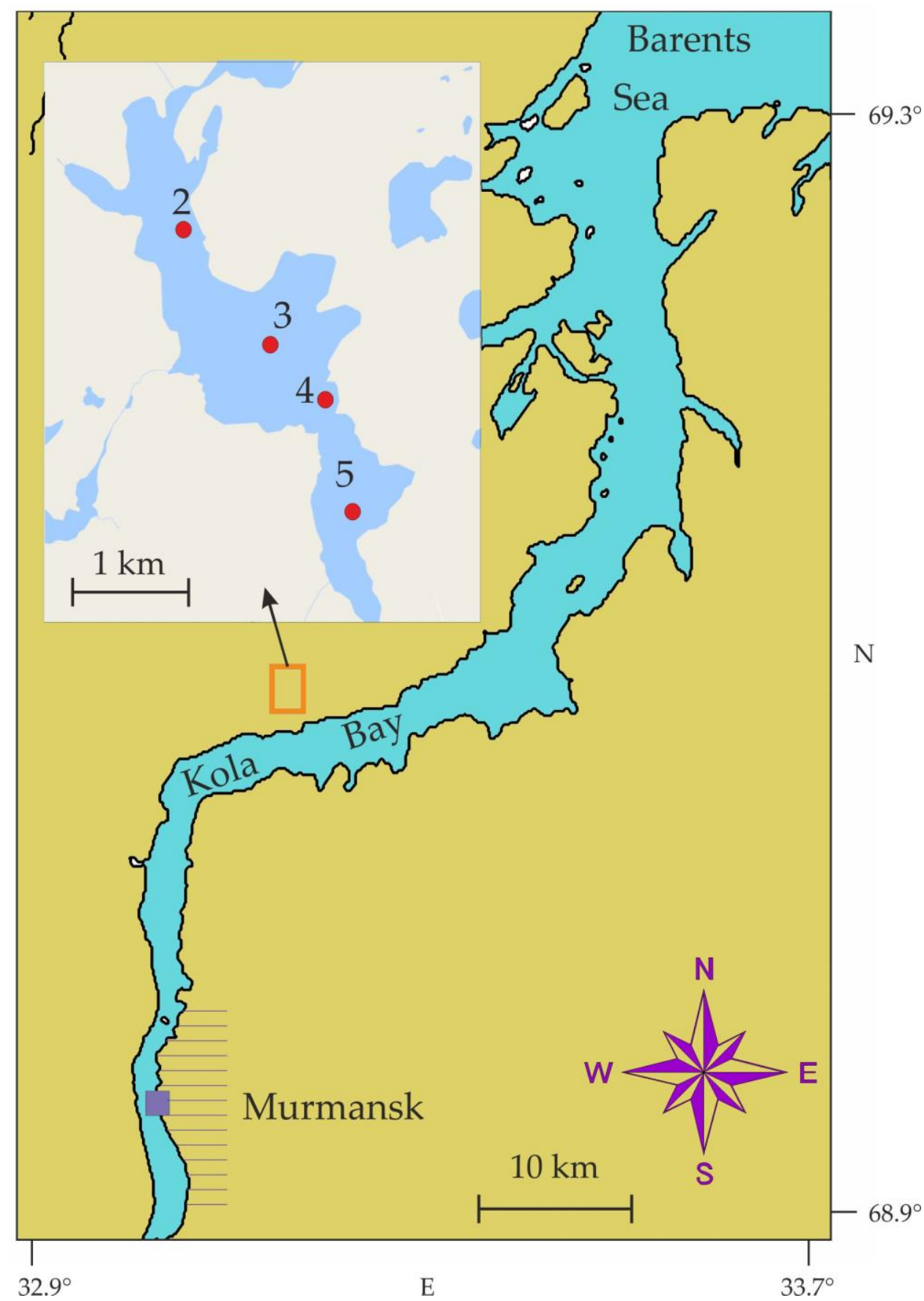

Figure 2. Location of zooplankton sampling stations (red circles) in Lake Kulonga, March 2016. Purple square indicates location of Murmansk.

Sampling was done using a 5 L Niskin bottle (General Oceanic, Miami, Florida, FL, USA) at every $5 \mathrm{~m}$ in the whole water layer. Samples were filtered through a sieve ( $50 \mu \mathrm{m})$ and preserved immediately with $4 \%$ formalin. A total of 39 samples were collected. Samples were processed using routine methods in the laboratory [12]. Zooplankton samples were analyzed in a Bogorov counting chamber using a stereomicroscope (MBS-10) (Lytkarino Optical Glass Factory, Moscow, Russia) or a Leica microscope (Leica Microsystems, Wetzlar, Germany) at $16 \times$ to $100 \times$ magnification and identified to the genus or species level according to standard taxonomic guides [26,27].

Zooplankton biomass for different species was calculated based on the standard masses or empirical length-weight regressions [28,29]. Mean values are presented with standard errors $( \pm \mathrm{SE})$. 
A hierarchical cluster analysis of the similarity between stations was performed on the basis of a Bray-Curtis similarity index and square-root-transformed abundance data using the PRIMER statistical package version 5.0 [30]. We consider that the similarity level $>30 \%$ provides good delineation between cluster groups [30]. The contribution of common zooplankton taxa to the total similarity within the different groups of stations was computed using SIMPER (similarity percentages breakdown) procedure.

\section{Results}

Air temperature varied from -4 to $-2{ }^{\circ} \mathrm{C}$ while water temperature in the whole water layer ranged from 0.7 to $3.3^{\circ} \mathrm{C}$, with a maximum located near the bottom (Table 1).

Table 1. A list of zooplankton sampling stations and environmental variables in Lake Kulonga in March 2016.

\begin{tabular}{cccccccc}
\hline St. & Date & Coordinates & Local Time & Depth, $\mathbf{m}$ & $\begin{array}{c}\text { Snow } \\
\text { Thickness, } \mathbf{m}\end{array}$ & Ice Thickness, $\mathbf{m}$ & $\begin{array}{c}\text { Mean Water } \\
\text { Temperature, }{ }^{\circ} \mathbf{C}\end{array}$ \\
\hline 2 & 3 March 2016 & $\begin{array}{l}69^{\circ} 07.535^{\prime} \mathrm{N} \\
33^{\circ} 05.115^{\prime} \mathrm{E}\end{array}$ & $12: 07$ & 24 & 0.20 & 0.62 & 3.2 \\
3 & 4 March 2016 & $\begin{array}{l}69^{\circ} 06.991^{\prime} \mathrm{N} \\
33^{\circ} 06.356^{\prime} \mathrm{E}\end{array}$ & $11: 15$ & 13 & 0.18 & 0.60 & 2.8 \\
4 & 4 March 2016 & $\begin{array}{l}69^{\circ} 06.774^{\prime} \mathrm{N} \\
33^{\circ} 06.799^{\prime} \mathrm{E}\end{array}$ & $13: 33$ & 2 & 0.40 & 0.63 & 0.8 \\
5 & 4 March 2016 & $\begin{array}{l}69^{\circ} 06.353^{\prime} \mathrm{N} \\
33^{\circ} 07.281^{\prime} \mathrm{E}\end{array}$ & $14: 59$ & 4 & 0.15 & 0.65 & 1.0 \\
\hline
\end{tabular}

A total of nine zooplankton species were identified during the study period in Lake Kulonga (Table 2).

Table 2. The abundance (individuals $\mathrm{m}^{-3}$ )/ biomass ( $\mathrm{mg}$ wet mass $\mathrm{m}^{-3}$ ) of zooplankton taxa in Lake Kulonga in March 2016.

\begin{tabular}{|c|c|c|c|c|}
\hline \multirow{2}{*}{ Taxon } & \multicolumn{4}{|c|}{ Station } \\
\hline & 2 & 3 & 4 & 5 \\
\hline \multicolumn{5}{|c|}{ Cyclopoida } \\
\hline Acanthocyclops vernalis & $120 / 6.4$ & $50 / 2.4$ & - & - \\
\hline Cyclops scutifer & $120 / 13.6$ & - & - & $67 / 5.7$ \\
\hline Cyclops strenuus & $40 / 5.3$ & - & - & - \\
\hline Cyclops vicinus & $80 / 7.2$ & - & - & - \\
\hline Cyclops spp. IV-V & $320 / 2.4$ & $300 / 2.2$ & $200 / 1.8$ & $133 / 0.9$ \\
\hline Mesocyclops leuckarti & $280 / 5.1$ & $100 / 2$ & - & $200 / 4.2$ \\
\hline Macrocyclops albidus & $120 / 22.1$ & $50 / 12.7$ & - & - \\
\hline Eucyclops serrulatus & $80 / 4.1$ & $100 / 4.7$ & - & - \\
\hline \multicolumn{5}{|c|}{ Calanoida } \\
\hline Eudiaptomus gracilis & $80 / 3.4$ & $200 / 7.9$ & - & - \\
\hline Eudiaptomus graciloides & $80 / 3.1$ & $50 / 1.8$ & - & - \\
\hline
\end{tabular}

Note. «-»—not found.

These belonged to Copepoda with Cyclopoida being the most representative taxa (7 species) (Table 2). All the taxa were found at deep-water stations (Stations 2 and 3), while only three taxa were registered at shallow-water stations.

The total abundance of zooplankton in Lake Kulonga varied from 200 to 1320 ind. $\mathrm{m}^{-3}$, averaging $705 \pm 252$ ind. $\mathrm{m}^{-3}$ (Table 2). Cyclopoida and Calanoida accounted for $603 \pm 207$ and $103 \pm 62$ ind. $\mathrm{m}^{-3}$, respectively. Total wet biomass of zooplankton during the study period ranged between 1.8 and $72.8 \mathrm{mg}^{-3}$ wet mass $\mathrm{m}^{-3}$ (Table 2) with a mean of $29.8 \pm 15.8 \mathrm{mg} \mathrm{m}^{-3}$ (Table 2). Average values for Cyclopoida and Calanoida were $26 \pm 14$ and $4 \pm 2 \mathrm{mg} \mathrm{m}^{-3}$, respectively. The mean abundance of zooplankton was $1110 \pm 300$ ind. $\mathrm{m}^{-3}$ at deep-water stations and $300 \pm 83$ ind. $\mathrm{m}^{-3}$ at shallow-water stations. The average zooplankton biomass was estimated to be $53.2 \pm 16.2 \mathrm{mg}$ wet mass $\mathrm{m}^{-3}$ and 
$6.3 \pm 3.7 \mathrm{mg}$ wet mass $\mathrm{m}^{-3}$ at deep-water and shallow-water locations, respectively. Old copepodites of Cyclops spp. prevailed at deep-water stations (Table 2), comprising 24-33\% of the total zooplankton abundance. The copepods Mesocyclops leuckarti and Eudiaptomus gracilis also had a high relative abundance accounting for $11-21 \%$ and $6-21 \%$ in the total zooplankton abundance, respectively.

The copepods Cyclops spp. IV-V were the most abundant at shallow-water stations where these animals attained up to $100 \%$ in the total zooplankton number. The copepod Macrocyclops albidus dominated at deep-water stations in terms of the total zooplankton biomass (Table 2), its proportion was 30-33\%. Other species were prevailing by the zooplankton biomass at shallow water stations, namely, Cyclops scutifer and Cyclops spp. (Table 2). The Shannon diversity index of the total assemblage varied from 0 (Station 4 ) to 3.05 (Station 2).

A cluster analysis based on zooplankton species abundance found two primary groups at a $37 \%$ level of similarity within the study area (Figure 3).

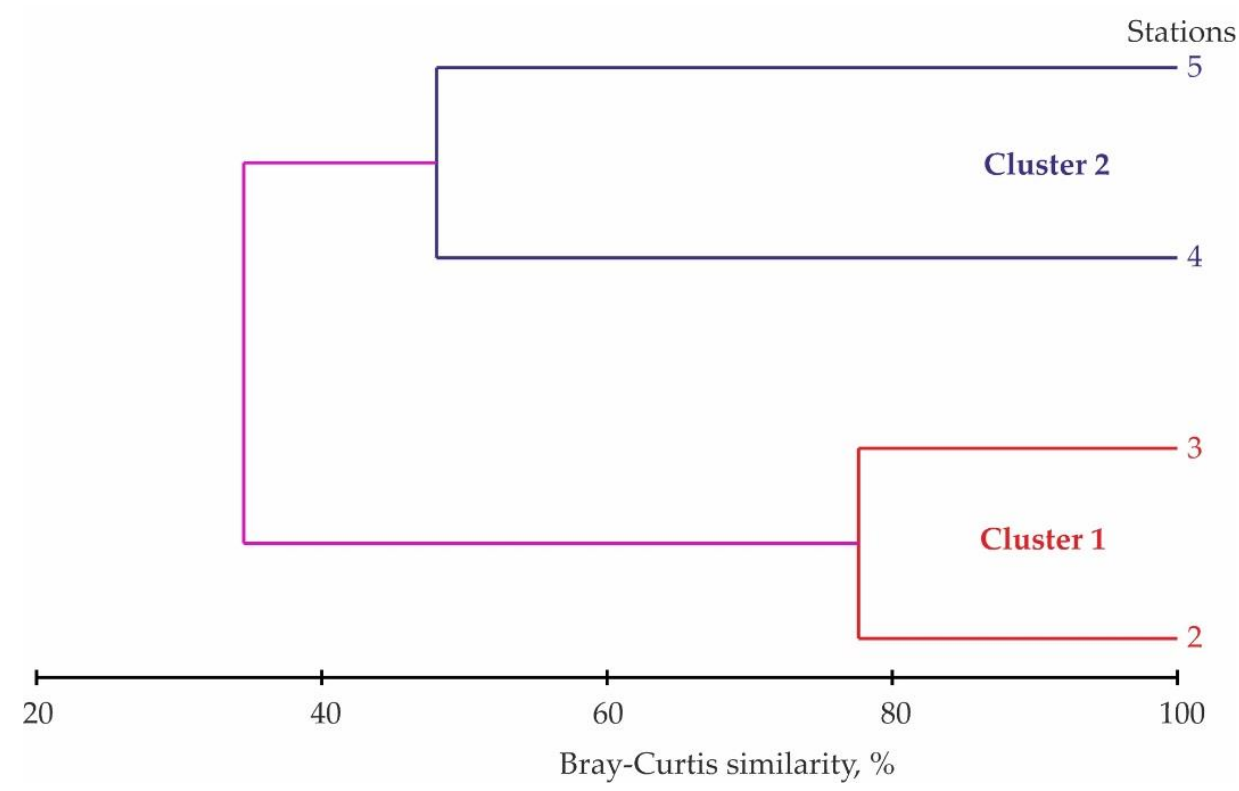

Figure 3. The results of cluster analyses (group-average method) based on the square-root transformed abundance of zooplankton in Lake Kulonga in March 2016.

The first group consisted of two stations located in the central and northern part of the lake. The similarity index for Stations 2 and 3 was $78 \%$. Dominant taxa of this community included Cyclops sp. IV-V and Mesocyclops leuckarti. The second group included two stations located in the central and southern part of the lake. The similarity index for Stations 4 and 5 was $47 \%$. The second community was exclusively dominated by Cyclopoida. The first cluster was characterized by the highest mean zooplankton abundance and biomass. The values recorded in the first group were four and eight times higher than in the second group. SIMPER analysis showed that four taxa primarily accounted for observed differences in zooplankton assemblages between two station groups delineated with cluster analysis (Table 3). 
Table 3. SIMPER: List of taxa that contributed the most to the dissimilarity within groups delineated with cluster analysis in Lake Kulonga in March 2016.

\begin{tabular}{ccc}
\hline Taxa & Average Dissimilarity, \% & Contribution, \% \\
\hline Eudiaptomus gracilis & 17.05 & 17.05 \\
Cyclops spp. IV-V & 15.96 & 33.02 \\
Mesocyclops leuckarti & 15.63 & 48.65 \\
Eucyclops serrulatus & 10.47 & 59.12 \\
Acanthocyclops vernalis & 9.12 & 68.65 \\
Macrocyclops albidus & 9.12 & 77.37 \\
\hline
\end{tabular}

The vertical distribution of zooplankton in Lake Kulonga was specific (Figure 4).
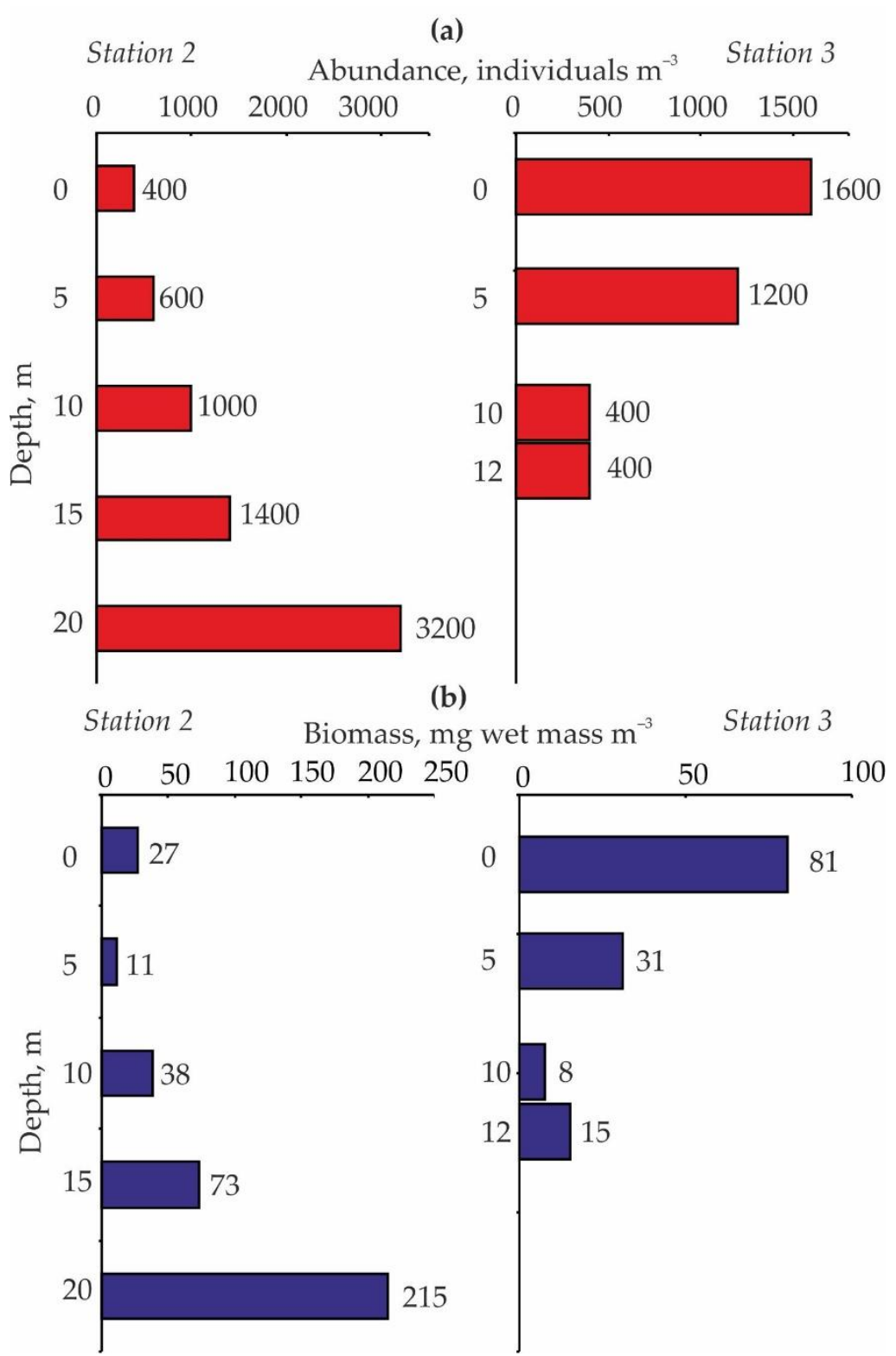

Figure 4. The vertical distribution of zooplankton abundance, ind. $\mathrm{m}^{-3}$ (a) and biomass, $\mathrm{mg}$ wet mass $\mathrm{m}^{-3}(\mathbf{b})$ in Lake Kulonga in March 2016.

The highest abundance of zooplankton at Station 2 was recorded near the bottom (3200 ind. $\mathrm{m}^{-3}$ ). There was a declining trend in the total number of zooplankton from the bottom to the surface with a minimum $\left(400\right.$ ind. $\left.\mathrm{m}^{-3}\right)$ in the upper layer (Figure 4). 
In contrast, the total zooplankton abundance demonstrated an increasing pattern from the bottom to the surface at Station 3.

\section{Discussion}

Freshwater ecological systems in general, and lakes in particular, play an important role in regulating ecosystem dynamics and they supply humans with many ecosystem advantages and services; including drinking water, sources of aquatic animals and plants, and locations for recreational fishing and cruises [5,31]. But, despite all that, information on the zooplankton composition in lakes of the Kola Peninsula is scarce. The main bulk of the data refer to the summer seasons (Table 4).

Previous studies have shown that zooplankton composition is poor in small oligotrophic lakes. Usually, in the western part of the Murmansk region, 15-20 taxa can be found during the summer period including 10-12 species of Rotatoria, 3-5 species of Cladocera, and 3-5 copepod taxa [13], while in the central part summer zooplankton are composed of 27-30 taxa including Rotifera (9 species), Cladocera (10 species), and Copepoda (8 species) [15].

The main taxa dominating the zooplankton are the rotatorins Keratella cochlearis and Kellicottia longispina, the cladoceran Bosmina obtusirostris, and the copepod Eudiaptomus graciloides.

The Shannon index for the total zooplankton community varied from 1.05-2.9, being higher in the central part of the Kola Peninsula. The total zooplankton abundance is three times lower in the western part compared to the central part of the peninsula (Table 4).

In the small lakes of the northern taiga in the Kola Peninsula, summer plankton fauna is similar to the community registered in lakes from the central part of the Kola Peninsula in terms of species composition, abundance, and biomass [16]. Summer zooplankton diversity, abundance, and biomass in sub-arctic lakes situated in the Republic of Karelia are higher compared to the Kola Peninsula $[32,33]$.

We found that the species richness, abundance, and biomass of the zooplankton assemblage were low in Lake Kulonga and this pattern thus seems to be quite specific for the winter season. Although the first regular investigations in the Arctic suggested that ice-covered regions were generally unproductive. More recent studies revealed significant productivity under ice-covered water bodies $[34,35]$ and the existence of productive areas, indicating the significance of the complex links between ice, ocean, and land in the Arctic [36]. Studies conducted by Russian planktonologists showed a clear decline and absence of rotatorians during the winter period in small water bodies and streams of the Kola Peninsula $[21,22,37]$. At the same time, the proportion of planktonic crustaceans demonstrates an increasing pattern in both the zooplankton abundance and biomass [37]. 
Table 4. The zooplankton of oligotrophic lakes in the Russian sub-arctic zone.

\begin{tabular}{|c|c|c|c|c|c|c|c|}
\hline Lake & Region & Coordinates & Dominating Taxa & Abundance, ind. $\mathrm{m}^{-3}$ & Biomass, $\mathrm{g}$ wet mass $\mathrm{m}^{-3}$ & Shannon Index & Reference \\
\hline & \multicolumn{7}{|c|}{ Summer } \\
\hline Imandra & $\begin{array}{c}\text { Kola Peninsula, central } \\
\text { part }\end{array}$ & $67^{\circ} 40^{\prime} \mathrm{N}, 33^{\circ} 00^{\prime} \mathrm{E}$ & $\begin{array}{l}\text { Bosmina obtusirostris } \\
\text { Daphnia cristata } \\
\text { Holopedium gibberum } \\
\text { Mesocyclops leuckarti } \\
\text { Eudiaptomus gracilis }\end{array}$ & 69,000 & 0.4 & $1.7-2.9$ & [15] \\
\hline $\begin{array}{l}\text { Verhniy } \\
\text { Tsagajavr }\end{array}$ & $\begin{array}{c}\text { Kola Peninsula, central } \\
\text { part }\end{array}$ & $67^{\circ} 33^{\prime} \mathrm{N}, 35^{\circ} 07^{\prime} \mathrm{E}$ & $\begin{array}{l}\text { Kellicottia longispina } \\
\text { Bosmina obtusirostris } \\
\text { Holopedium gibberum } \\
\text { Daphnia cristata } \\
\text { Eudiaptomus gracilis }\end{array}$ & 37,500 & 0.94 & 1.65 & [16] \\
\hline $\begin{array}{l}\text { Nizhniy } \\
\text { Tsagajavr }\end{array}$ & $\begin{array}{c}\text { Kola Peninsula, central } \\
\text { part }\end{array}$ & $67^{\circ} 34^{\prime} \mathrm{N}, 35^{\circ} 07^{\prime} \mathrm{E}$ & $\begin{array}{l}\text { Keratella cochlearis } \\
\text { Bosmina obtusirostris } \\
\text { Cyclops sp. }\end{array}$ & 2250 & 0.06 & 1.22 & [16] \\
\hline Sharjavr & $\begin{array}{c}\text { Kola Peninsula, central } \\
\text { part }\end{array}$ & $67^{\circ} 33^{\prime} \mathrm{N}, 35^{\circ} 8^{\prime} \mathrm{E}$ & $\begin{array}{c}\text { Keratella cochlearis } \\
\text { Kellicottia longispina } \\
\text { Daphnia cristata } \\
\text { Eudiaptomus gracilis } \\
\text { Cyclops sp. }\end{array}$ & 10,950 & 0.52 & 2.06 & [16] \\
\hline Goluboe & $\begin{array}{c}\text { Kola Peninsula, central } \\
\text { part }\end{array}$ & $67^{\circ} 27^{\prime} \mathrm{N}, 35^{\circ} 07^{\prime} \mathrm{E}$ & $\begin{array}{c}\text { Keratella cochlearis } \\
\text { Kellicottia longispina } \\
\text { Holopedium gibberum } \\
\text { Bosmina obtusirostris } \\
\text { Eudiaptomus gracilis } \\
\text { Cyclops sp. }\end{array}$ & 14,080 & 0.32 & 2.48 & [16] \\
\hline Verhne-Panskoe & $\begin{array}{c}\text { Kola Peninsula, central } \\
\text { part }\end{array}$ & $67^{\circ} 26^{\prime} \mathrm{N}, 35^{\circ} 11^{\prime} \mathrm{E}$ & $\begin{array}{l}\text { Kellicottia longispina } \\
\text { Bosmina obtusirostris } \\
\text { Cyclops sp. }\end{array}$ & 1500 & 0.04 & 1.98 & [16] \\
\hline
\end{tabular}


Table 4. Cont

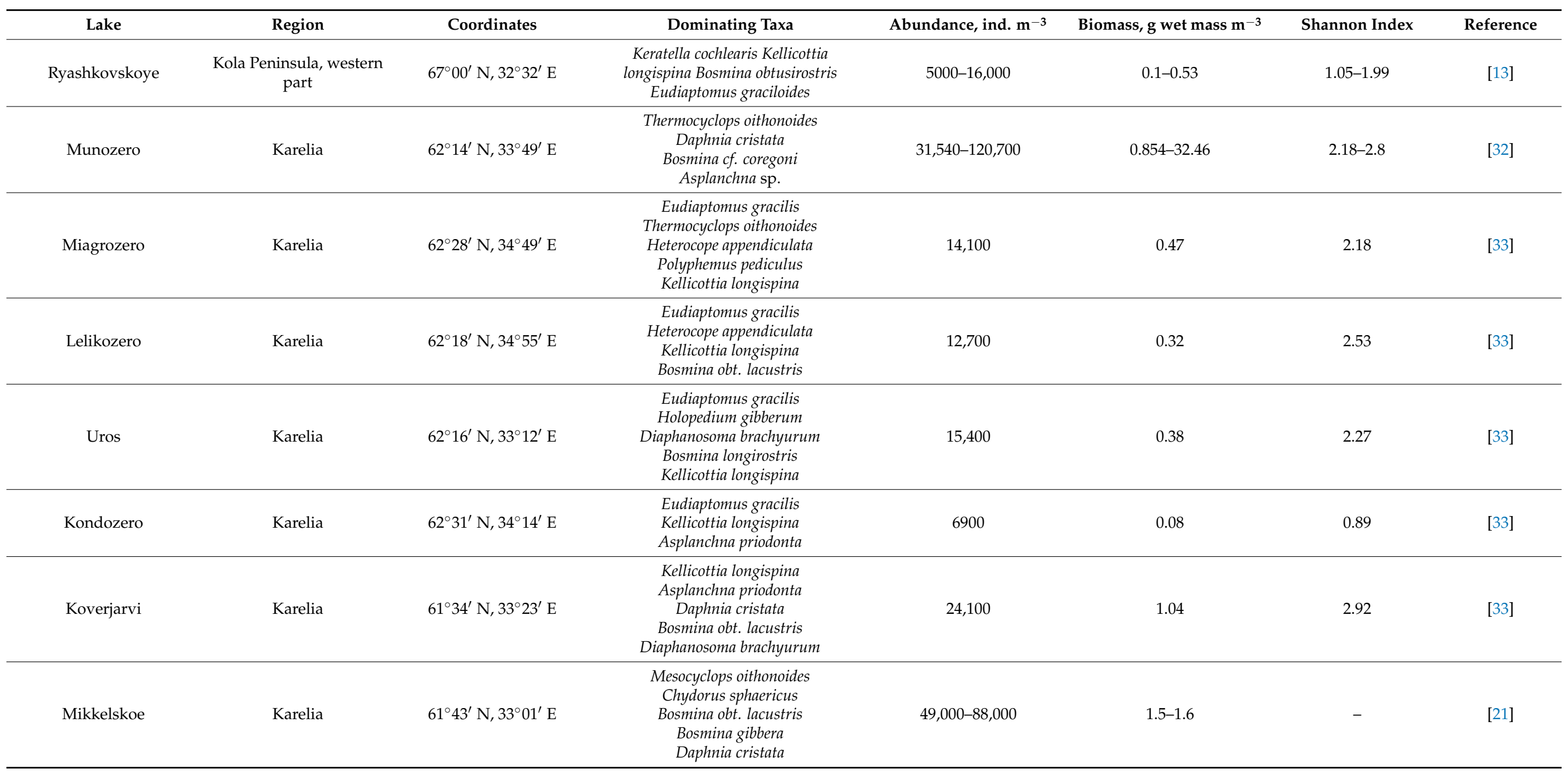


Table 4. Cont

\begin{tabular}{|c|c|c|c|c|c|c|c|}
\hline Lake & Region & Coordinates & Dominating Taxa & Abundance, ind. $\mathrm{m}^{-3}$ & Biomass, $\mathrm{g}$ wet mass $\mathrm{m}^{-3}$ & Shannon Index & Reference \\
\hline Kroshnozero & Karelia & $61^{\circ} 40^{\prime} \mathrm{N}, 33^{\circ} 07^{\prime} \mathrm{E}$ & $\begin{array}{l}\text { Mesocyclops oithonoides } \\
\text { Mesocyclops leuckarti } \\
\text { Bosmina obt. lacustris } \\
\text { Daphnia cristata } \\
\text { Chydorus sphaericus }\end{array}$ & $86,200-110,000$ & $1.5-1.7$ & - & [21] \\
\hline \multirow[t]{2}{*}{ Onego } & Karelia & $61^{\circ} 46^{\prime} \mathrm{N}, 34^{\circ} 30^{\prime} \mathrm{E}$ & $\begin{array}{l}\text { Limnocalanus macrurus } \\
\text { Bosmina longispina } \\
\text { Daphnia cristata } \\
\text { Kellicottia longispina } \\
\text { Asplanchna sp. }\end{array}$ & 5600 & 0.21 & - & [11] \\
\hline & \multicolumn{7}{|c|}{ Winter } \\
\hline Mikkelskoe & Karelia & $61^{\circ} 43^{\prime} \mathrm{N}, 33^{\circ} 01^{\prime} \mathrm{E}$ & $\begin{array}{c}\text { Eudiaptomus gracilis } \\
\text { Cyclops sp. } \\
\text { Daphnia cristata } \\
\text { Asplanchna priodonta }\end{array}$ & 2818 & $0.02-0.06$ & - & [21] \\
\hline Kroshnozero & Karelia & $61^{\circ} 40^{\prime} \mathrm{N}, 33^{\circ} 07^{\prime} \mathrm{E}$ & $\begin{array}{c}\text { Eudiaptomus gracilis } \\
\text { Eudiaptomus graciloides } \\
\text { Daphnia cristata } \\
\text { Notholca longispina }\end{array}$ & $4635-5120$ & $0.1-0.2$ & - & [21] \\
\hline Kulonga & $\begin{array}{l}\text { Kola Peninsula, } \\
\text { northern part }\end{array}$ & $69^{\circ} 06^{\prime} \mathrm{N}, 33^{\circ} 06^{\prime} \mathrm{E}$ & $\begin{array}{c}\text { Cyclops spp. } \\
\text { Macrocyclops albidus } \\
\text { Cyclops scutifer }\end{array}$ & $200-1320$ & $0.018-0.073$ & 1.77 & Our data \\
\hline
\end{tabular}


In our study, the zooplankton assemblage of Lake Kulonga in March 2016 was composed totally of copepods with no rotatorians and cladocerans. A dominance of cyclopoid copepods is a typical feature of winter zooplankton in sub-arctic lakes of Russia (Table 4). Cladocerans and rotatorians have life cycles with many rapidly reproducing parthenogenetic generations in summer. Sexually mature females and males occur during a short, favorable season, usually from late summer to autumn. Fertilized resting eggs overwinter in the bottom sediment and their development begins after the resting period [5,12]. In our study, the water temperature was low and stable within the entire water column at all stations. We suggest that this factor may explain the absence of rotatorians and cladocerans which prefer warmer conditions [11,21]. Moreover, globally copepods present a significant part in freshwater zooplankton all year round [37-39]. Our estimations of the total abundance of zooplankton during the study period were comparable with previous values of 2500-7000 ind. $\mathrm{m}^{-3}$ recorded in aquatic ecosystems in north-western regions of Russia [11,22]. At the same time, the total zooplankton biomass in our study was somewhat lower compared with the values registered in more southern regions (Karelia) where it was estimated to be 60-270 $\mathrm{mg}$ of wet mass $\mathrm{m}^{-3}$ in the winter period (Table 4). Also, the total number of species (13) was higher than in Lake Kulonga. Such differences appear to be associated with many factors including geographical location, trophic status, predator density, and food supply. It is known that zooplankton productivity tends to be reduced in the northern regions due to severe conditions, such as the shorter duration of daylight and the lower water temperatures [37,38].

We found that the vertical distribution of zooplankton differed considerably at two deep-water stations despite the high similarity index found for these areas. At the station situated in the central part of the lake (Station 3), zooplankton abundance increased as depth decreased whereas, at the station situated near the north-eastern coast (Station 2), we registered a reverse pattern (Figure 3). In general, the distribution patterns of zooplankton are a result of their vertical migrations. Migrations can be driven by predation, food availability as well as light and temperature regimes [37,40]. We recorded similar light intensity at stations 1, 2 and 4. Therefore, in our case, the light regime seems to have high relevance for Station 3 where the light intensity was higher compared to other locations. In the Arctic, the light intensity is a crucial factor contributing to the vertical distribution of zooplankton assemblages in winter because the lakes are ice-covered [5,12]. Also, the oxygen concentration demonstrated a clear pattern: an increase from the bottom to the surface accounted for $12.4,8.4,5.3$, and $3.3 \mathrm{mg} \mathrm{L}^{-1}$ at $0,5,10$, and $25 \mathrm{~m}$ depth, respectively [25]. Better light levels and oxygen conditions in the shallow waters are preferable for zooplankton in terms of the greater feeding opportunities compared to deeper waters. Better temperature conditions were registered for Station 2 and a similar vertical distribution of zooplankton would be expected for this area because the aquatic organisms usually migrate from the cold waters towards the warmer layer $[40,41]$. The highest abundance was, however, registered in the bottom water layer, indicating that abiotic factors had low importance in this case and that this pattern may be interpreted as a consequence of the predator-prey interactions. Ichthyofauna of Lake Kulonga is poor: only five species are registered here including one gasterosteid species (three-spined stickleback (Gasterosteus aculeatus)), three salmonid species (Atlantic salmon (Salmo salar), brown trout (Salmo trutta), and Arctic charr (Salvelinus alpinus)) and one coregonid species (European whitefish (Coregonus lavaretus)) [42]. Sticklebacks were the most abundant, while the appearance of Atlantic salmons and whitefish were rare occurrences in the lake [42]. Stomach content analyses revealed that Arctic charrs and brown trouts fed on benthic animals while sticklebacks had a wide and flexible trophic niche being both planktivorous and benthivorous. In the winter of 2016, the highest fish densities occurred in the coastal areas of Lake Kulonga at 2.5-4.5 m [42]. In the central part, fish abundance was low. Thus, we can assume that an inverse pattern in the vertical distribution of zooplankton registered at the coastal site of the lake is associated with the high density of potential predators. Planktonic animals have been shown to avoid the deep layers of lakes in response to chemical cues released in the 
water by fish predators. While in periods when the mortality risk from fish is reduced, zooplankton migrate to the upper layer and graze on abundant microalgae [40,43]. Fish predation also explains why the average abundance and biomass were much higher at deep-water stations compared to shallow-water stations.

\section{Conclusions}

The present study provides a baseline description of winter zooplankton in Lake Kulonga, a site selected for extensive exploration. We found relatively low species richness and abundance indices of zooplankton as a result of severe light and thermal conditions in winter. Cyclopoid copepods dominated the winter community in terms of total abundance and biomass. The vertical distribution of zooplankton reflects certain patterns in food availability and is an important part of predator-prey relationships. Our data may be useful for the future monitoring of zooplankton at this site after the establishment of the complex for manufacturing large marine structures and also in comparative studies of plankton biota in other aquatic ecosystems at high latitudes.

Author Contributions: Conceptualization, V.G.D.; methodology, V.G.D.; formal analysis, V.G.D. and A.G.D., investigation, V.G.D. and A.G.D.; data curation, V.G.D.; visualization, A.G.D.; writingoriginal draft preparation, V.G.D. and A.G.D. All authors have read and agreed to the published version of the manuscript.

Funding: This study was funded by the Ministry of Science and Higher Education of the Russian Federation.

Institutional Review Board Statement: Not applicable.

Informed Consent Statement: Not applicable.

Data Availability Statement: The data are available on request from the corresponding author.

Acknowledgments: We are grateful to A.A. Frolov for help in sampling and photographs.

Conflicts of Interest: The authors declare no conflict of interest.

\section{References}

1. Williams, R.; Conway, D.V.P.; Hunt, H.G. The role of copepods in the planktonic ecosystems of mixed and stratified waters of the European shelf seas. Hydrobiologia 1994, 292, 521-530. [CrossRef]

2. Hudson, J.; Taylor, W.; Schindler, D. Planktonic nutrient regeneration and cycling efficiency in temperate lakes. Nature 1999, 400, 659-661. [CrossRef]

3. Dvoretsky, V.G.; Dvoretsky, A.G. Macrozooplankton of the Arctic-The Kara Sea in relation to environmental conditions. Estuar. Coast. Shelf Sci. 2017, 88, 38-55. [CrossRef]

4. Dvoretsky, V.G.; Dvoretsky, A.G. Mesozooplankton in the Kola Transect (Barents Sea): Autumn and winter structure. J. Sea Res. 2018, 142, 18-22. [CrossRef]

5. Lampert, W.; Sommer, U. Limnolecology: The Ecology of Lakes and Streams; Oxford University Press: New York, NY, USA, 1998.

6. Dvoretsky, V.G.; Dvoretsky, A.G. Summer macrozooplankton assemblages of Arctic shelf: A latitudinal study. Cont. Shelf Res. 2019, 188, 103967. [CrossRef]

7. Dvoretsky, V.G.; Dvoretsky, A.G. Arctic marine mesozooplankton at the beginning of the polar night: A case study for southern and south-western Svalbard waters. Polar Biol. 2020, 43, 71-79. [CrossRef]

8. Dvoretsky, V.G.; Dvoretsky, A.G. Summer variability of reproductive pattern in the marine cladoceran Evadne nordmanni in Arctic waters. J. Sea Res. 2020, 166, 101969. [CrossRef]

9. Beaver, J.R.; Arp, C.D.; Tausz, C.E.; Jones, B.M.; Whitman, M.S.; Renicker, T.R.; Samples, E.E.; Ordosch, D.M.; Scotese, K.C. Potential shifts in zooplankton community structure in response to changing ice regimes and hydrologic connectivity. Arctic Antarctic Alpine Res. 2019, 51, 327-345. [CrossRef]

10. Rautio, M.; Bayly, I.A.E.; Gibson, J.A.E.; Nyman, M. Zooplankton and zoobenthos in high-latitude water bodies. In Polar Lakes and Rivers: Limnology of Arctic and Antarctic Aquatic Ecosystems; Vincent, W.G., Laybourn-Parry, J., Eds.; Oxford University Press: Oxford, UK, 2000; pp. 231-247.

11. Fomina, Y.Y.; Syarki, M.T. Modern state of zooplankton and its response to climate change in Petrozavodsk Bay of Lake Onego. Proc. Karelian Res. Centre RAS 2018, 9, 54-64. (In Russian) [CrossRef]

12. Wetzel, R.G. Limnology: Lake and River Ecosystems; Academic: San Diego, CA, USA, 2001. 
13. Vandysh, O.I. The current state of zooplankton community in Lake Ryashkovskoye (Murmansk oblast). Inland Water Biol. 2010, 3, 135-141. [CrossRef]

14. Symons, C.C.; Pedruski, M.T.; Arnott, S.E.; Sweetman, J.N. Spatial, environmental, and biotic determinants of zooplankton community composition in subarctic lakes and ponds in Wapusk National Park, Canada. Arctic Antarctic Alpine Res. 2014, 46, 159-190. [CrossRef]

15. Vandysh, O.I.; Kashulin, N.A.; Cherepanov, A.A. Long-term changes of zooplankton communities in Imandra Lake under multilevel pollution by mining production runoffs. Herald Kola Sci. Centre RAS 2014, 2, 121-129. (In Russian)

16. Valkova, S.A.; Denisov, D.B.; Terentyev, P.M.; Vandysh, O.I.; Kashulin, N.A. Hydrobiological characteristics of some small lakes in the northern taiga zone (Kola Peninsula). Proc. Karelian Res. Centre. RAS 2015, 4, 79-93. (In Russian) [CrossRef]

17. Hampton, S.E.; Moore, M.V.; Ozersky, T.; Stanley, E.H.; Polashenski, C.M.; Galloway, A.W.E. Heating up a cold subject: Prospects for under-ice plankton research in lakes. J. Plankton Res. 2015, 37, 277-284. [CrossRef]

18. Berge, J.; Renaud, P.E.; Darnis, G.; Cottier, C.; Last, K.; Gabrielsen, T.M.; Johnsen, G.; Seuthe, L.; Weslawski, J.M.; Leu, E.; et al. In the dark: A review of ecosystem processes during the Arctic polar night. Prog. Oceanogr. 2015, 139, $258-271$.

19. Berge, J.; Cottier, F.; Last, K.S.; Varpe, Ø.; Leu, E.; Soreide, J.; Eiane, K.; Falk-Petersen, S.; Willis, K.; Nygard, H.; et al. Diel vertical migration of Arctic zooplankton during the polar night. Biol. Let. 2009, 5, 69-72. [CrossRef]

20. Błędzki, L.A.; Rybak, J.I. Freshwater Crustacean Zooplankton of Europe; Springer International Publishing: Cham, Switzerland, 2016.

21. Filimonova, Z.I. Zooplankton of Mikkelskoe and Kroshnozero lakes and their significance in feeding of fish. Proc. Karel. Branch USSR Acad. Sci. 1956, 2, 89-124. (In Russian)

22. Filimonova, Z.I. Zooplankton of Kuito lake and their seasonal dynamics. In Conference Abstract of Conference in 1962; Institute of Biology of Karelian Branch of USSR Academy Sciences: Petrozavodsk, Russia, 1963; pp. 148-150. (In Russian)

23. Carrozzo, D.; Musazzi, S.; Lami, A.; Córdoba, F.E.; González Sagrario, M.Á. Changes in planktivory and herbivory regimes in a shallow south american lake (Lake Blanca Chica, Argentina) over the last 250 years. Water 2020, 12, 597. [CrossRef]

24. Magnuson, J.J.; Robertson, D.M.; Benson, B.J.; Wynne, R.H.; Livingstone, D.M.; Arai, T.; Assel, R.A.; Barry, R.G.; Card, V.; Kuusisto, E.; et al. Historical trends in lake and river ice cover in the northern hemisphere. Science 2000, 289, 1743-1746. [CrossRef] [PubMed]

25. Frolov, A.A. Description of the study area. In Engineering and Environmental Research for the Object Center for Construction of Large-Capacity Marine Structures (CSCMS) in the Village Area Belokamenka. Volume 2 (Lake Kulonga); Ishkulov, D.G., Frolov, A.A., Eds.; MMBI KSC RAS Press: Murmansk Russia, 2016; pp. 6-11. (In Russian)

26. Einsle, U. Copepoda: Cyclopoida, Genera Cyclops, Megacyclops, Acanthocyclops. Guides to the Identification of the Microinvertebrates of the Continental Waters of the World No.10; SPB Academic Publishing: London, UK, 1996.

27. Båtnes, A.S.; Miljeteig, C.; Berge, J.; Greenacre, M.; Johnsen, G. Quantifying the light sensitivity of Calanus spp. during the polar night: Potential for orchestrated migrations conducted by ambient light from the sun, moon, or aurora borealis? Polar Biol. 2015, 38, 51-65. [CrossRef]

28. Chislenko, L.L. Nomogrammes to Determine Weights of Aquatic Organisms Based on the Size and form of Their Bodies (Marine Mesobenthos and Plankton); Nauka Press: Saint Petersburg, Russia, 1968. (In Russian)

29. McCauley, E. The estimation of the abundance and biomass of zooplankton in samples. In Manual on Methods for the Assessment of Secondary Productivity in Fresh Water; Downing, J.A., Rigler, F.H.A., Eds.; Blackwell: St Louis, MO, USA, $1984 ;$ pp. $228-265$.

30. Clarke, K.R.; Gorley, R.N. PRIMER v5: User Manual/Tutorial; PRIMER-E Ltd.: Plymouth, UK, 2001.

31. Ditton, R.B.; Holland, S.M.; Anderson, D.K. Recreational fishing as tourism. Fisheries 2002, 27, 17-24. [CrossRef]

32. Syarki, M.T.; Fomina, Y.Y. Current state of zooplankton of Lake Munozero (Republic of Karelia, Russia). Ecosyst. Transform. 2020, 3, 11-18. [CrossRef]

33. Kulikova, T.P. Zooplankton in Waters of the White Sea Drainage Basin; Karelian Res. Centre, Russian Acad. Sci.: Petrozavodsk, Russia, 2010. (In Russian)

34. Dvoretsky, V.G.; Dvoretsky, A.G. Distribution of the under-ice mesozooplankton in the Kara Sea (February 2002). Polar Biol. 2009, 32, 1227-1231. [CrossRef]

35. Dvoretsky, V.G.; Dvoretsky, A.G. Early winter mesozooplankton of the coastal south-eastern Barents Sea. Estuar. Coast. Shelf Sci. 2015, 152, 116-123. [CrossRef]

36. Berge, J.; Cottier, F.; Varpe, Ø.; Renaud, P.E.; Falk-Petersen, S.; Kwasniewski, S.; Griffiths, C.; Søreide, J.E.; Johnsen, G.; Aubert, A.; et al. Arctic complexity: A case study on diel vertical migration of zooplankton. J. Plankton Res. 2014, 36, 1279-1297. [CrossRef] [PubMed]

37. Kulikova, T.P.; Ryabinkin, A.V. Zooplankton and macrozoobenthos in small reservoirs in different types of landscapes in southern Karelia. Proc. Karelian Res. Centre RAS 2015, 6, 47-63. (In Russian) [CrossRef]

38. Rautio, M.; Sorvari, S.; Korhola, A. Diatom and crustacean zooplankton communities, their seasonal variability and representation in the sediments of subarctic Lake Saanajarvi. J. Limnol. 2000, 59, 81-96. [CrossRef]

39. Krupa, E.; Romanova, S.; Berkinbaev, G.; Yakovleva, N.; Sadvakasov, E. Zooplankton as indicator of the ecological state of protected aquatic ecosystems (Lake Borovoe, Burabay National Nature Park, Northern Kazakhstan). Water 2020, $12,2580$. [CrossRef]

40. Simoncelli, S.; Thackeray, S.J.; Wain, D.J. Effect of temperature on zooplankton vertical migration velocity. Hydrobiologia 2019, 829, 143-166. [CrossRef] 
41. Larsen, P.S.; Madsen, C.V.; Riisgård, H.U. Effect of temperature and viscosity on swimming velocity of the copepod Acartia tonsa, brine shrimp Artemia salina and rotifer Brachionus plicatilis. Aquat. Biol. 2008, 4, 47-54. [CrossRef]

42. Frolov, A.A. Ichthyofauna. In Engineering and Environmental Research for the Object Center for Construction of Large-Capacity Marine Structures (CSCMS) in the Village Area Belokamenka. Volume 2 (Lake Kulonga); Ishkulov, D.G., Frolov, A.A., Eds.; MMBI KSC RAS Press: Murmansk, Russia, 2016; pp. 47-63. (In Russian)

43. Cohen, J.H.; Forward, R.B. Zooplankton diel vertical migration-A review of proximate control. Oceanogr. Mar. Biol. Ann. Rev. $2009,47,77-110$. 